\title{
PENGARUH DISIPLIN KERJA, MOTIVASI KERJA DAN KOMPENSASI TERHADAP KINERJA PEGAWAI BANK OCBC NISP BAGIAN RECORD MANAGEMENT DAN PARTNERSHIP OPERATION
}

\author{
Asep Hardiansyah' Soehardi²; Zahara Tussoleha Rony 3 \\ Program Studi Magister Manajemen Fakultas Ekonomi Universitas Bhayangkara Jakarta \\ Raya $^{1,2,3}$ \\ asep.hardiansyah@yahoo.com ${ }^{1}$; soehardi@dsn.ubharajaya.ac.id ${ }^{2}$; zahara_ttv@yahoo.com³
}

\begin{abstract}
ABSTRAK
Penelitian ini bertujuan untuk mengetahui pengaruh disiplin kerja terhadap kinerja pegawai, pengaruh motivasi kerja terhadap kinerja pegawai bank, pengaruh kompensasi terhadap disiplin kerja pegawai, pengaruh motivasi kerja terhadap disiplin kerja pegawai, pengaruh kompensasi terhadap kinerja pegawai bank OCBC NISP pada bagian RCMPO. Penelitian ini menggunakan teknik sampling jenuh. Populasi penelitian ini adalah seluruh pegawai yang berada di Bagian Record Management dan Partnership Operation yang berjumlah 98 orang. Metode Penelitian ini menggunakan metode penelitian kuantitatif dengan program komputer Partial Least Square (PLS). Hasil penelitian menunjukkan tidak terdapat pengaruh yang signifikan Disiplin Kerja terhadap Kinerja Pegawai Bank OCBC NISP di Bagian RCMPO dengan nilai $T$ Statistics 0.981 lebih kecil dari t table 1.96. Tidak terdapat pengaruh yang signifikan Motivasi Kerja terhadap Kinerja Pegawai Bank OCBC NISP di Bagian RCMPO dengan nilai $T$ Statistics 0,282 lebih kecil dari t table 1.96. Terdapat pengaruh yang signifikan Kompensasi terhadap Disiplin Kerja pada Bank OCBC NISP di Bagian RCMPO dengan nilai TStatistics lebih besar dari t table 7,352 lebih besar dari t table_1.96. Terdapat pengaruh yang signifikan Motivasi Kerja terhadap Disiplin Kerja pada Bank OCBC NISP di Bagian RCMPO dengan nilai T Statistics 24,184 lebih besar dari t table 1.96. Terdapat pengaruh yang signifikan Kompensasi terhadap Kinerja Pegawai pada Bank OCBC NISP di Bagian RCMPO dengan nilai T Statistics 5,779 lebih besar dari t table 1.96.
\end{abstract}

Kata Kunci: Disiplin Kerja, Motivasi Kerja, Kompensasi, Kinerja Pegawai, Structural Equation Modeling dan Partial Least Square.

\section{EFFECT OF WORK DISCIPLINE, WORK MOTIVATION AND COMPENSATION OF BANK \\ OCBC NISP EMPLOYEE PERFORMANCE PART RECORD MANAGEMENT AND}

PARTNERSHIP OPERATION

ABSTRACT

This study aims to determine (1) the effect of Work Discipline on the Performance of Bank OCBC NISP's Employees in the RCMPO section; (2) the influence of Work Motivation on the Performance of Bank OCBC NISP's Employees in the RCMPO section; (3) the effect of Compensation on Bank OCBC NISP Employee Discipline in the RCMPO section; (4) the influence of Work Motivation on the Work Discipline of Bank OCBC NISP Employees in the RCMPO section; (5) the effect of Compensation on the Performance of Bank OCBC NISP's Employees in the RCMPO section. This study uses a saturated sampling technique. The study population was all employees in the Record Management and Partnership Operations Section, totaling 98 people. This research method uses quantitative research methods with a Partial Least Square (PLS) computer program. The results showed no significant effect of Work 
148 | Jurnal Ilmiah Manajemen Ubhara, Volume 6 No 2, Oktober 2019. ISSN 1858 - 1358, E - ISSN 2684 - 7000.

Discipline on the Performance of Bank OCBC NISP's Employees in the RCMPO Section with a T value of Statistics 0.981 is smaller than t table 1.96. There is no significant influence of Work Motivation on the Performance of Bank OCBC NISP Employees in the RCMPO Section with a $T$ Statistics value of 0.282 is smaller than $t$ table 1.96. There is a significant effect of Compensation on Work Discipline at Bank OCBC NISP in the RCMPO Section with a value of T Statistics 7.352 $t$ count is greater than t table 1.96. There is a significant influence of Work Motivation on Work Discipline at Bank OCBC NISP in the RCMPO Section with a T Statistics 24,184 t count is greater than t table 1.96. There is a significant effect of Compensation on Employee Performance at Bank OCBC NISP in the RCMPO Section with a T value of Statistics 5.779 t count is greater than table 1.96 .

\section{Keywords: Work Discipline, Work Motivation, Compensation, Employee Performance, Structural Equation Modeling and Partial Least Square}

Diterima: 15 Agust 2019; Direvisi: 16 Sept 2019; Diterbitkan: 30 Okt 2019

\section{PENDAHULUAN}

Permasalahan mengenai sumber daya manusia pada saat sekarang ini masih menjadi pusat perhatian dan tumpuhan utama bagi perusahaan swasta ataupun instansi pamerintahan dimanapun berada. Pegawai merupakan sumber daya yang berperan aktif dan dominan dalam setiap kegia

tan perusahaan. Pegawai menjadi perencana, pelaku, dan penentu terwujudnya tujuan organisasi. Selain itu pegawai merupakan sumber daya unik yang memiliki pikiran, perasaan, keinginan, status, dan latar belakang heterogen. Apabila pengelolaan karyawan dilakukan dengan baik maka perusahaan akan mendapatkan sumber daya yang unggul. Oleh karena itu pengelolaan pegawai dalam organisasi sangatlah penting bagi pencapaian keberhasilan organisasi.

Kinerja pada Record Management dan Partnership Operation (RCMPO) yang merupakan bagian dari Operation Process Division pada Bank OCBC NISP di Jakarta belum maksimal, hal ini bisa dilihat dari hasil survey internal pada tahun 2016 yang diselenggarakan oleh pihak manajemen Bank OCBC NISP di awal tahun 2017, survey ini dilakukan untuk mengetahui seberapa baik tingkat kinerja masing-masing bagian dari tiap-tiap divisi selama tahun 2016.

Ada beberapa dokumen dari cabang yang dikirimkan ke RCMPO setiap harinya, dokumen tersebut adalah seperti dokumen pembukaan rekening tabungan, pembukaan rekening giro, pembukaan rekening deposito, transaksi pembelian reksadana dan lain-lain. Dokumen-dokumen tersebut selanjutnya di scan dan diurut sesuai dengan jenis dokumen nya masing-masing, kemudian di upload pada sistem Bank, hal ini diperlukan jika dikemudian hari cabang memerlukan dokumen nasabah tersebut, jadi cabang hanya perlu masuk pada sistem, maka semua dokumen yang diperlukan akan ditampilkan. Namun hal tersebut masih banyak dikeluhkan oleh beberapa cabang, keluhannya adalah masih terdapat beberapa dokumen setelah $\mathrm{H}+3$ sejak dokumen itu dikirimkan ke RCMPO namun masih belum bisa diakses pada sistem, sehingga akhirnya dokumen tersebut harus di scan manual dan dikirimkan melalui email ke cabang. Selain memerlukan waktu yang lebih lama, hal ini juga akan menimbulkan production cost. Mengapa hal ini bisa terjadi, sesuai dengan hasil wawancara penulis kepada manajer RCMPO, hal ini disebabkan karena target harian yang telah ditentukan oleh atasan masih belum bisa dicapai oleh pegawai RCMPO. Sebetulnya jika melihat ke komposisi pekerja, dibagian penerimaan dokumen terdapat 5 orang pegawai, namun target masih belum bisa tercapai.

Selanjutnya mengenai Service Level Agreement (SLA) bekaitan Rekening Koran, SLA rekening koran untuk nasabah yang berada di wilayah JABODETABEK seharusnya sudah diterima oleh pihak nasabah pada minggu ke-2 setiap bulannya dari tanggal cetak, sedangkan diluar JABODETABEK seharusnya rekening koran sudah diterima oleh nasabah pada minggu ke-3 dari tanggal cetak, namun pada kenyataannya masih terdapat keluhan yang masuk ke RCMPO mengenai belum diterima nya rekening koran oleh nasabah. Bahkan mengenai keluhan rekening koran ini, terdapat nasabah yang 
sudah lebih dari 1 bulan namun laporan rekening koran nya masih belum diterima. Mengapa hal ini bisa terjadi, sesuai dengan hasil wawancara penulis kepada Manajer RCMPO, hal ini disebabkan karena adanya perubahan alamat pengiriman rekening koran nasabah, namun data yang berada di vendor masih menggunakan alamat yang lama, sehingga rekening koran masih terkirim ke alamat yang lama. Koordinasi antara RCMPO dengan vendor mesti ditingkatkan kembali, supaya hal ini tidak terus terjadi, dan perlu adanya sistem baru yang harus dikembangkan oleh RCMPO untuk bisa mengakomodir jika terjadi perubahan alamat pengiriman rekening koran, vendor langsung bisa mengakses report ini.

Masih ditemukan beberapa pegawai yang tidak mengikuti aturan yang diberlakukan oleh perusahaan, diantaranya mengenai peraturan jam kerja yang berlaku. Seorang pegawai dalam 1 hari efektifnya bekerja selama 8 jam, mulai dari jam 08:00-17:00 dan jam 12:0013:00 ditetapkan sebagai jam istirahat, namun masih ditemukan pegawai yang masih sibuk dengan gudget nya masing-masing, padahal bila dilihat waktu sudah menunjukan diatas jam 08:00 yang mana pada jam tersebut seharusnya pegawai sudah memulai aktivitasnya dengan baik. Pada siang hari setelah jam istirahat selesai yaitu diatas jam 13:00, masih ada pegawai yang masih asik mengobrol dengan temanya yang lain, padahal jika melihat aturan yang berlaku, diatas jam 13:00 pegawai harus sudah mulai beraktivitas (bekerja) kembali.

Selanjutnya penurunan kinerja pegawai pada Bagian RCMPO juga dapat dilihat pada Motivasi Kerja. Dari hasil wawancara penulis dengan 36 pegawai dengan level officer dan 6 pegawai dengan level Supervisor di Bagian RCMPO pada tanggal 19-22 September 2017. disampaikan mengenai hal-hal berkaitan untuk memotivasi kerja pegawai di Bagian RCMPO belum maksimal, diantaranya:

Yang pertama mengenai asuransi kesehatan (tidak termasuk BPJS). Jika dibandingkan dengan perusahaan sejenis seperti Bank Standard Chartered, limit asuransi kesehatan yang diberikan perusahaan tersebut untuk rawat inap dalam 1 tahun adalah unlimited, sedangkan Bank OCBC NISP untuk rawat inap memberikan plafond bagi pegawainya yaitu sebesar Rp 100,000,000 per tahun.

Selanjutnya mengenai insentif, insentif menghubungkan penghargaan dan kinerja dengan memberikan imbalan kinerja kinerja tidak berdasarkan senioritas atau jam bekerja. Program insentif dirancang untuk meningkatkan motivasi kerja pekerja. Program insentif dapat berupa insentif perorangan, insentif untuk seluruh perusahaan, dan program tunjangan (Wibowo, 2015 h 301). Di Bank OCBC NISP belum ada insentif bagi pegawainya yang memiliki kinerja baik dalam 1 bulan, contohnya insentif bagi pegawai yang dalam 1 (satu) bulan tidak pernah terlambat datang ke kantor, jika dilihat di perusahaan lain seperti PT ASKRINDO, manejmen ASKRINDO akan memberikan insentif (premi kehadiran) bagi pegawainya yang dalam 1 bulan tidak pernah terlambat datang ke kantor, besar insentif yang diberikan adalah sebesar Rp 450,000.

Kompensasi sangat penting bagi pegawai, hal ini karena kompensasi merupakan sumber penghasilan bagi pegawai dan keluarganya. Menurut perundang-undangan yang berlaku, komposisi dibagi menjadi 2 yang didasari perilakunya. Kompensasi bersifat normatif adalah kompensasi minimum yang harus diterima, yang terdiri atas gaji atau upah (termasuk didalamnya gaji/upah pokok, tunjangan tetap), dan komponen lainnya, seperti tunjangan kesehatan dan tunjangan hari raya/keagamaan. Dilihat dari sisi normatif, kompensasi yang diterima oleh pegawai Bank OCBC NISP khususnya di bagian RCMPO belum cukup baik, pertama mengenai Upah/Gaji dan Komponen tetap, dari hasil wawancara penulis pada tanggal 2529 September 2017 pada 43 pegawai dengan level officer, rata-rata gaji pegawai dengan level officer dikisaran Rp 3,500,000-Rp 4,800,000 (tidak termasuk uang lembur/over 
time), hal ini hampir mendekati UMP Bekasi tahun 2016 yaitu sebesar Rp 3,100,000.

Hal lainnya masih terdapat kekurangan pada kompensasi yang bersifat kebijakan yaitu mengenai kebijakan berupa reward, dibuktikan dengan masih rendahnya reward yang diterima oleh pegawai, sebagai contoh, setiap tahun manajemen mengadakan Quality Competition, isi dari kompetisi ini adalah mengadu ide/gagasan, inovasi mengenai bagaimana cara kita agar bisa menurunkan cost dalam setiap pekerjaan dan harus tetap produktif, dan kemudian dituangkan dalam sebuah laporan dan dipresentasikan dihadapan atasang masing-masing, dan bagi pegawai yang berhasil masuk ke dalam 10 besar quality competition tersebut hanya mendapatkan reward sebesar $\mathrm{Rp}$ 500,000 (tidak termasuk pemenang juara 3 sampai juara 1), hal ini dipandang tidak sebanding dengan apa yang telah dilakukan pegawai, jika dilihat dari cost saving pegawai bisa menurunkan cost mulai dari jutaan rupiah bahkan hingga ratusan juta rupiah per tahun. Dari wawancara penulis dengan salah satu pegawai, mengatakan adanya ketidak adilan dalam pemberian reward seperti yang diutarakan Bapak Lukman berikut ini, "Belajar dari pengalaman pegawai lain yang pernah membuat PIT's dan bahkan masuk ke dalam 10 besar tapi tidak masuk ke dalam 3 besar pada Quality Competition, pegawai tersebut hanya mendapatkan reward sebesar Rp 500,000, sebetulnya jika dilihat dari cost saving, PIT's yang mereka buat bisa menurunkan cost sampai 30,000,000, bisa dilihat dalam hal ini ide atau sesuatu yang kita buat untuk perusahaan tidak sebanding dengan apa yang kita terima, ini alasan kenapa teman-teman yang lain tidak termotivasi untuk membuat PIT's atau Campaign 3LoD."

\section{KAJIAN TEORETIK}

\section{Kinerja}

Menurut Colquitt (2015, h 33) Job performance is the set of employee behaviors that contribute to organizational goal accomplishment. Kinerja adalah seperangkat perilaku karyawan yang berkontribusi terhadap pencapaian tujuan organisasi.

Kinerja merupakan implementasi dari teori keseimbangan, yang mengatakan bahwa seseorang akan menunjukan prestasi yang optimal apabila ia mendapatkan manfaat (benefit) dan terdapat adanya rangsangan (inducement) dalam pekerjaannya secara adil dan masuk akal. Wexley and Yukl dalam Sinambela (2012, h 8).

Selanjutnya menurut Schermerhorn (2010, h 130) Performance is influenced most directly by individual attributes such as ability and experience; organizational support such as resources and technology; and effort, or the willingness of someone to work hard at what they are doing. Kinerja dipengaruhi secara langsung oleh atribut individu seperti kemampuan dan pengalaman, dukungan organisasi seperti sumber daya dan teknologi, dan usaha atau kemauan seseorang untuk bekerja keras pada apa yang mereka lakukan.

Kinerja Pegawai didefinisikan sebagai kemampuan pegawai dalam melakukan suatu keahlian tertentu. Kinerja pegawai sangatlah perlu, sebab dengan kinerja ini akan diketahui seberapa jauh kemampaun pegawai dalam melaksanakan tugas yang dibebankan kepadanya. Untuk itu diperlukan penentuan kriteria yang jelas dan terukur serta ditetapkan secara bersama-sama yang dijadikan sebagai acuan (Sinambela, 2011, h 480).

Edison (2017, h 192), menambahkan bahwa untuk mencapai atau menilai kinerja, ada dimensi yang menjadi tolok ukur, berikut adalah deskripsi dari dimensi kinerja:

1. Target. Target merupakan indikator terhadap pemenuhan jumlah barang, pekerjaan, atau jumlah uang yang dihasilkan.

2. Kualitas. Kualitas terhadap hasil yang dicapai, dan ini adalah elemen penting, karena kualitas merupakan kekuatan dalam mempertahankan kepuasan customer.

3. Waktu Penyelesaian. Penyelesaian yang tepat waktu dan/atau penyerahan pekerjaan menjadi pasti. Ini adalah modal 
untuk membuat kepercayaan pelanggan. Pengertian pelanggan disini berlaku juga terhadap layanan pada bagian lain dilingkup internal perusahaan/organisasi.

4. Taat Asas. Tidak saja harus memenuhi target, kualitas dan tepat waktu tapi juga harus dilakukan dengan cara yang benar, jtransfaran dan dapat dipertanggungjawab.

\section{Disiplin Kerja}

1. Menurut Hani Handoko berpendapat bahwa pendisiplinan untuk memperbaiki kegiatan di waktu yang akan datang bukan menghukum kegiatan di masa lalu. Sementara itu, sasaran-sasaran tindakan pendisiplinan hendaknya positif yang berifat mendidik dan mengoreksi, bukan tindakan negatif yang menjatuhkan pegawainya yang berbuat salah. Tindakan negatif ini biasanya mempunyai berbagai pengaruh sampingan yang merugikan seperti hubungan emosional terganggu, absensi meningkat, antipati atau kelesuan, dan ketakutan pada penyelia.

2. Menurut Bejo Siswanto menguraikan bahwa maksud dan sasaran dari disiplin kerja adalah terpenuhinya beberapa tujuan seperti:

a. Tujuan umum disiplin kerja. Tujuan umum disiplin kerja adalah demi kelangsungan perusahaan sesuai dengan motif organisasi bagi yang bersangkutan baik hari ini, maupun hari esok.

b. Tujuan khusus disiplin kerja. Tujuan khusus antara lain:

1) Untuk para pegawai menempati segala peraturan dan kebijakan ketenaga kerjaan maupun peraturan, serta kebijakan perusahaan yang berlaku, baik yang tertulis maupun yang tidak tertulis, serta melaksanakan perintah manajemen.

2) Dapat melaksanakan pekerjaan sebaik-baiknya, serta mampu memberikan service yang maksimum pada pihak tertentu yang berkepentingan dengan perusahaan sesuai dengan bidang pekerjaan yang telah diberikan kepadanya.

3) Dapat menggunakan dan memelihara sarana dan prasarana barang dan jasa perusahaan dengan sebaik-baiknya.

4) Dapat bertindak dengan berperilaku sesuai dengan norma-norma yang berlaku pada perusahaan.

5) Tenaga kerja mampu memperoleh tingkat produktivitasnya yang tinggi sesuai dengan harapan perusahaan, baik dalam jangka pendek maupun jangka panjang.

\section{Motivasi Kerja}

Sedangka menurut Abraham Maslow dalam Robbin (2013, h 203), ada lima jenjang kebutuhan yang tersusun dalam suatu hierarki, yaitu:

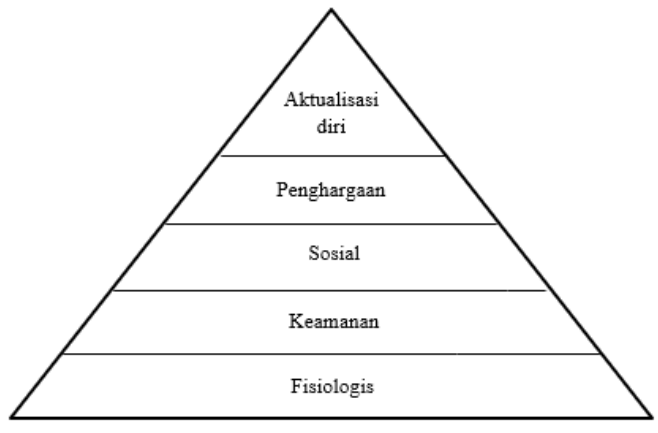

Gambar 1.

Hierarki Kebutuhan Maslow

1. Physiological needs, Kebutuhan fisiologis. Yang termasuk kelompok ini adalah kebutuhan paling dasar, seperti mendapatkan makanan, air, udara, istirahat, dan hubungan seksual. Kebutuhan dasar ini muncul lebih dulu sebelum keinginan pada jenjang kedua, yaitu kebutuhan akan rasa aman.

2. Safety needs atau security needs, Kebutuhan akan rasa aman mencakup semua kebutuhan terhadap lingkungan yang aman dan terlindungi, baik secara fisik maupun emosi, serta bebas dari ancaman 
termasuk lingkungan yang tertib dan kemerdekaan dari tindak kekerasan.

3. Affection needs atau love needs atau belonging needs, Kebutuhan untuk disukai (rasa memiliki, sosial, dan cinta) merupakan kebutuhan yang lebih tinggi, setelah terpenuhi kebutuhan dasar fisik dan rasa amannya.

4. Esteem needs, Kebutuhan harga diri. Pada tingkatan ini, individu memiliki kebutuhan untuk berprestasi dan mendapat pengakuan serta penghargaan dari orang lain.

5. Self-actualization needs, Kebutuhan pengembangan diri atau aktualisasi diri. Ini merupakan kebutuhan pada hierarki tertinggi, yaitu memenuhi diri sendiri dengan memaksimalkan keahlian dan potensi yang ada.

Alderfer setuju dengan pendapat Abraham Maslow bahwa setiap orang mempunyai kebutuhan yang tersusun dalam suatu hierarki. Tapi kebutuhan hierarki hanya meliputi tiga perangkat, yaitu:

1. Existence (kebutuhan akan eksistensi, yaitu kebutuhan yng dipuaskan oleh faktorfaktor seperti makanan, air, udara, dan istirahat).

2. Relatedness (kebutuhan untuk berhubungan dengan pihak yang lain, yaitu kebutuhan yang dipuaskan oleh hubungan sosial dan hubungan antar pribadi yang bermanfaat).

3. Growth (pertumbuhan, merupakan kebutuhan-kebutuhan yang dimiliki seseorang untuk mengembangkan keahlian, kreatif, dan produktif).

\section{Kompensasi}

Menurut Edison (2017, h 152) Kompensasi adalah sesuatu yang diterima karyawan atas jasa yang mereka sumbangkan pada pekerjaannya. Kompensasi merupakan bentuk imbalan (baik berbentuk uang maupun hadiah) yang diterima pegawai/karyawan atas usaha-usaha yang dihasilkannya. Kompensasi dibagi menjadi 2, yaitu:

1. Kompensasi bersifat normatif adalah kompensasi minimum yang harus diterima, yang terdiri atas gaji atau upah (termasuk didalamnya gaji/upah pokok, tunjangan tetap), dan komponen tetap lainnya., seperti tunjangan kesehatan, tunjangan hari raya/keagamaan.

2. Kompensasi bersifat kebijakan adalah kompensasi yang didasari kebijakan dan/atau karena pertimbangan khusus, seperti tunjangan profesional, tunjangan makan dan transport, bonus, uang cuti, dan liburan.

Wibowo (2015, h 289) menjelaskan bahwa Kompensasi merupakan kontra prestasi terhadap penggunaan tenaga atau jasa yang telah diberikan oleh tenaga kerja. Kompenasi merupakan jumlah paket yang ditawarkan organisasi kepada pekerja sebagai imbalan atas penggunaan tenaga kerjanya.

Menurut Ivncevich dalam Wibowo (2015, h 292), bahwa terdapat tujuh kriteria untuk efektivitas kompensasi, yaitu:

1. Tingkat kompensasi minimum yang harus dipenuhi baik oleh pemerintah, serikatt pekerja maupun manajer.

2. Setiap orang harus dibayar dengan jujur, sesuai dengan usaha, kemampuan, dan pelatihan mereka.

3. Bayaran, tunjangan dan penghargaan lain harus dapat memberikan paket imbalan yang layak.

4. Bayaran tidak boleh berlebihan, perlu mempertimbangkan apa yang dapat diusahakan oleh perusahaan atau organisasi untuk membayar.

5. Bayaran harus cukup untuk membantu pekerja merasa aman dan membantu memuaskan kebutuhan dasar mereka.

6. Bayaran harus memotivasi efektifitas dan pekerjaan harus produktif.

7. Pekerja harus memahami sistem bayaran dan merasakan sebagai sistem yang layak untuk perusahaan atau organisasi diri mereka.

\section{Kerangka Berpikir dan Hipotesis}




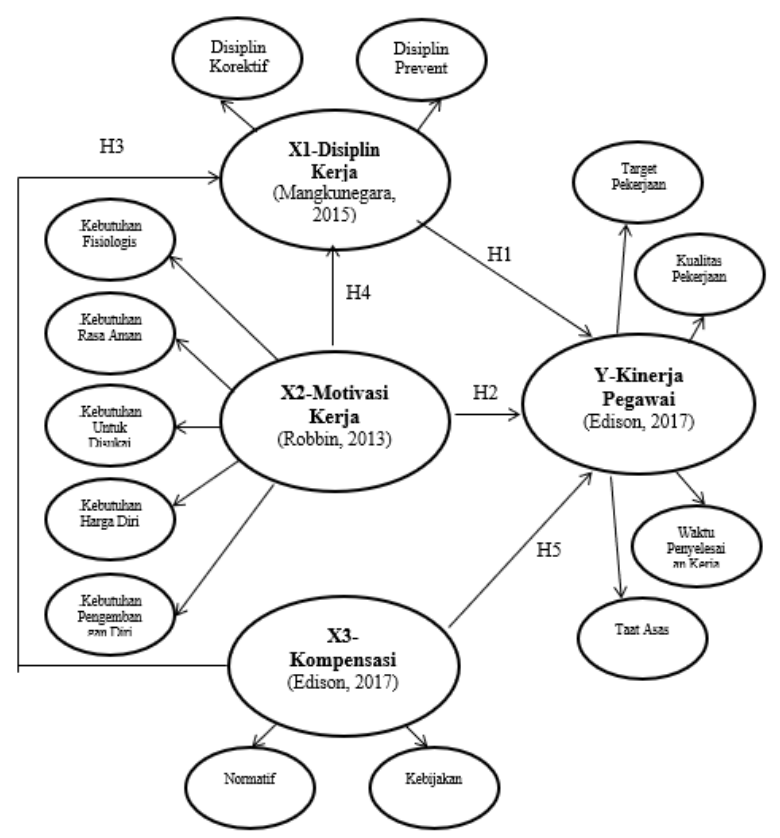

Gambar 2.

Kerangka Berpikir

\section{Metode Penelitian}

Metode penelitian dalam penelitian ini adalah metode penelitian kuantitatif dengan menggunakan program komputer Partial Least Square (PLS) dan teknik pengumpulan data yang digunakan dalam penelitian ini adalah dengan metode survei. Pengumpulan data dilakukan dengan menggunakan kuesioner. Teknik sampling dalam penelitian ini, peneliti akan menggunakan teknik sampling jenuh yaitu teknik penentuan sampel. Teknik analisis data yang digunakan dalam penelitian ini menggunakan metode Structural Equation Modeling (SEM). Metode SEM saat ini diperkirakan sebagai metode multivariate yang paling dominan. Program komputer yang saat ini dapat digunakan untuk mengolah data pada penelitian metode SEM diantaranya LISREL,

\section{HASIL PENELITIAN DAN PEMBAHASAN}

Tabel 1.

Data Umum Responden

\begin{tabular}{|c|l|c|c|}
\hline $\begin{array}{c}\text { Nomo } \\
\mathbf{r}\end{array}$ & \multicolumn{1}{|c|}{ Keterangan } & Jumlah & $\begin{array}{c}\text { Persentas } \\
\mathbf{e}\end{array}$ \\
\hline 1. & Jenis Kelamin
\end{tabular}

Tabel 2.

Nilai Loading Factor

\begin{tabular}{|l|c|c|c|c|}
\hline & $\begin{array}{c}\text { DK } \\
(\mathrm{X} 1)\end{array}$ & $\begin{array}{c}\text { MK } \\
(\mathrm{X} 2)\end{array}$ & $\begin{array}{c}\text { KO } \\
(\mathrm{X} 3)\end{array}$ & $\begin{array}{c}\text { KA } \\
(\mathrm{Y} 1)\end{array}$ \\
\hline DK01 & 0,740 & & & \\
\hline DK02 & 0,777 & & & \\
\hline DK04 & 0,715 & & & \\
\hline DK05 & 0,822 & & & \\
\hline DK09 & 0,651 & & & \\
\hline DK10 & 0,817 & & & \\
\hline MK01 & & 0,964 & & \\
\hline MK02 & & 0,805 & & \\
\hline MK03 & & 0,816 & & \\
\hline MK04 & & 0,965 & & \\
\hline MK05 & & 0,850 & & \\
\hline MK06 & & 0,860 & & \\
\hline MK07 & & 0,862 & & \\
\hline
\end{tabular}


154 | Jurnal Ilmiah Manajemen Ubhara, Volume 6 No 2, Oktober 2019. ISSN 1858 - 1358, E - ISSN 2684 - 7000.

\begin{tabular}{|c|c|c|c|}
\hline MKo8 & 0,665 & & \\
\hline MKo9 & 0,719 & & \\
\hline MK10 & 0,865 & & \\
\hline KOo1 & & 0,849 & \\
\hline KOO2 & & 0,876 & \\
\hline KOO3 & & 0,815 & \\
\hline KOO4 & & 0,837 & \\
\hline KOO5 & & 0,840 & \\
\hline KOo6 & & 0,823 & \\
\hline KOo7 & & 0,787 & \\
\hline KOo8 & & 0,721 & \\
\hline KOo9 & & 0,819 & \\
\hline KO10 & & 0,708 & \\
\hline KO11 & & 0,720 & \\
\hline KO12 & & 0,827 & \\
\hline KO13 & & 0,826 & \\
\hline KO14 & & 0,886 & \\
\hline KA01 & & & 0,734 \\
\hline KAO2 & & & 0,762 \\
\hline KAO5 & & & 0,891 \\
\hline KAo6 & & & 0,883 \\
\hline KA10 & & & 0,756 \\
\hline
\end{tabular}

Sumber : data diolah

\begin{tabular}{|c|c|c|c|c|c|}
\hline $\begin{array}{l}\mathrm{KOO} 2<-- \\
\mathrm{KO}\left(\mathrm{X}_{3}\right)\end{array}$ & 0,876 & 0,868 & 0,042 & 20,967 & 0,000 \\
\hline $\begin{array}{l}\mathrm{KOO} 3<-- \\
\mathrm{KO}\left(\mathrm{X}_{3}\right)\end{array}$ & 0,815 & 0,822 & 0,043 & 18,777 & 0,000 \\
\hline $\begin{array}{l}\mathrm{KOO} 4<-- \\
\mathrm{KO}\left(\mathrm{X}_{3}\right)\end{array}$ & 0,837 & 0,842 & 0,028 & 29,842 & 0,000 \\
\hline $\begin{array}{l}\text { KOO5<-- } \\
\mathrm{KO}\left(\mathrm{X}_{3}\right)\end{array}$ & 0,840 & 0,832 & 0,046 & 18,400 & 0,000 \\
\hline $\begin{array}{l}\text { KOo6<-- } \\
\mathrm{KO}\left(\mathrm{X}_{3}\right)\end{array}$ & 0,823 & 0,813 & 0,060 & 13,624 & 0,000 \\
\hline $\mathrm{KOO}_{7<--} \mathrm{KO}\left(\mathrm{X}_{3}\right)$ & 0,787 & 0,780 & 0,050 & 15,751 & 0,000 \\
\hline $\begin{array}{l}\text { KOo8<-- } \\
\text { KO(X3) }\end{array}$ & 0,721 & 0,707 & 0,083 & 8,682 & 0,000 \\
\hline $\begin{array}{l}\text { KOo9<-- } \\
\text { KO(X3) }\end{array}$ & 0,819 & 0,808 & 0,061 & 13,429 & 0,000 \\
\hline $\mathrm{KO} 10<--\mathrm{KO}\left(\mathrm{X}_{3}\right)$ & 0,708 & 0,694 & 0,089 & 7,981 & 0,000 \\
\hline KO11<-- $\mathrm{KO}\left(\mathrm{X}_{3}\right)$ & 0,720 & 0,699 & 0,098 & 7,388 & 0,000 \\
\hline KO12<-- $\mathrm{KO}\left(\mathrm{X}_{3}\right)$ & 0,827 & 0,818 & 0,059 & 14,133 & 0,000 \\
\hline $\mathrm{KO}_{13<--} \mathrm{KO}\left(\mathrm{X}_{3}\right)$ & 0,826 & 0,820 & 0,040 & 20,724 & 0,000 \\
\hline KO14<-- KO(X3) & 0,886 & 0,879 & 0,035 & 25,205 & 0,000 \\
\hline $\begin{array}{l}\text { MKo1<-- } \\
\text { MK(X2) }\end{array}$ & 0,964 & 0,965 & 0,011 & 85,854 & 0,000 \\
\hline $\begin{array}{l}\text { MK02<-- } \\
\text { MK(X2) }\end{array}$ & 0,805 & 0,803 & 0,067 & 11,971 & 0,000 \\
\hline $\begin{array}{l}\text { MKo3<-- } \\
\text { MK(X2) }\end{array}$ & 0,816 & 0,819 & 0,054 & 15,052 & 0,000 \\
\hline $\begin{array}{l}\text { MKo4<-- } \\
\text { MK(X2) }\end{array}$ & 0,965 & 0,966 & 0,011 & 84,781 & 0,000 \\
\hline $\begin{array}{l}\text { MKo5<-- } \\
\text { MK(X2) }\end{array}$ & 0,850 & 0,850 & 0,055 & 15,542 & 0,000 \\
\hline $\begin{array}{l}\text { MKo6<-- } \\
\text { MK(X2) }\end{array}$ & 0,860 & 0,859 & 0,050 & 17,142 & 0,000 \\
\hline $\begin{array}{l}\text { MKo7<-- } \\
\text { MK(X2) }\end{array}$ & 0,862 & 0,856 & 0,047 & 18,248 & 0,000 \\
\hline $\begin{array}{l}\text { MKo8<-- } \\
\text { MK(X2) }\end{array}$ & o,665 & 0,675 & 0,069 & 9,614 & 0,000 \\
\hline $\begin{array}{l}\text { MKo9<-- } \\
\text { MK(X2) }\end{array}$ & 0,719 & 0,717 & 0,054 & 13,244 & 0,000 \\
\hline $\begin{array}{l}\text { MK1O<-- } \\
\text { MK(X2) }\end{array}$ & 0,865 & 0,864 & 0,051 & 17,113 & 0,000 \\
\hline
\end{tabular}

Nilai Alpha: o - 1 (semakin besar semakin reliable), semakin tinggi koefisien reliabilitas sebuah alat ukur, maka measurement error yang dimiliki oleh alat ukur tersebut semakin rendah dan hasil skor dari alat ukur tersebut semakin dapat dipercaya.

Tabel 4.

Coranbach's Alhpha

\begin{tabular}{|l|c|c|c|}
\hline Variabel & $\begin{array}{c}\text { Cronbach' } \\
\text { S Alpha }\end{array}$ & $\begin{array}{c}\text { Batas } \\
\text { Minima } \\
\mathbf{l}\end{array}$ & Keterangan \\
\hline $\begin{array}{l}\text { Disiplin } \\
\text { Kerja }\end{array}$ & 0,848 & 0,700 & Reliabel \\
\hline Kinerja & 0,900 & 0,700 & Reliabel \\
\hline Kompensasi & 0,962 & 0,700 & Reliabel \\
\hline $\begin{array}{l}\text { Motivasi } \\
\text { Kerja }\end{array}$ & 0,953 & 0,700 & Reliabel \\
\hline
\end{tabular}

Nilai Composite Reliability menunjukan internal consistency yaitu nilai composite 
reliability yang tinggi menunjukan nilai konsistensi dari masing-masing indikator dalam mengukur konstruknya. Berdasarkan gambar diatas dapat dilihat nilai Composite Reliability untuk masing-masing konstruk $\geq$ o,7 yang artinya konstruk reliabel.

Tabel 5 . Composite Reliability

\begin{tabular}{|l|c|c|c|}
\hline Variabel & $\begin{array}{c}\text { Composite } \\
\text { Reliability }\end{array}$ & $\begin{array}{c}\text { Batas } \\
\text { Minimal }\end{array}$ & Keterangan \\
\hline $\begin{array}{l}\text { Disiplin } \\
\text { Kerja }\end{array}$ & 0,888 & 0,700 & Reliabel \\
\hline Kinerja & 0,923 & 0,700 & Reliabel \\
\hline Kompensasi & 0,964 & 0,700 & Reliabel \\
\hline $\begin{array}{l}\text { Motivasi } \\
\text { Kerja }\end{array}$ & 0,960 & 0,700 & Reliabel \\
\hline
\end{tabular}

Nilai $A V E$ digunakan untuk mengukur banyaknya varians yang dapat ditangkap oleh konstruknya dibandingkan dengan variansi yang ditimbulkan oleh kesalahan pengukuran. Berdasarkan gambar diatas dapat dilihat nilai AVE untuk masing-masing konstruk diatas 0,5 yang artinya konstruk reliabel.

Tabel 6.

Avarage Variace Extracted (AVE)

\begin{tabular}{|l|c|c|c|}
\hline Variabel & AVE & $\begin{array}{c}\text { Batas } \\
\text { Minimal }\end{array}$ & Keterangan \\
\hline $\begin{array}{l}\text { Disiplin } \\
\text { Kerja }\end{array}$ & 0,572 & 0,500 & Reliabel \\
\hline Kinerja & 0,635 & 0,500 & Reliabel \\
\hline Kompensasi & 0,658 & 0,500 & Reliabel \\
\hline $\begin{array}{l}\text { Motivasi } \\
\text { Kerja }\end{array}$ & 0,709 & 0,500 & Reliabel \\
\hline
\end{tabular}

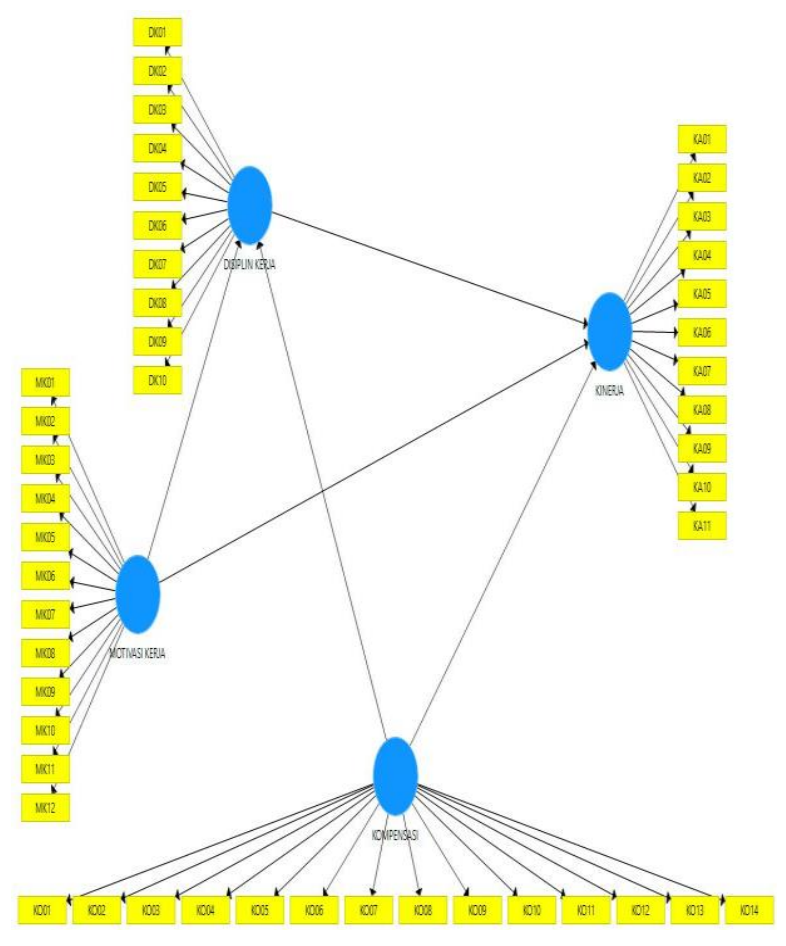

Gambar 3.

Diagram Model Utama Penelitian

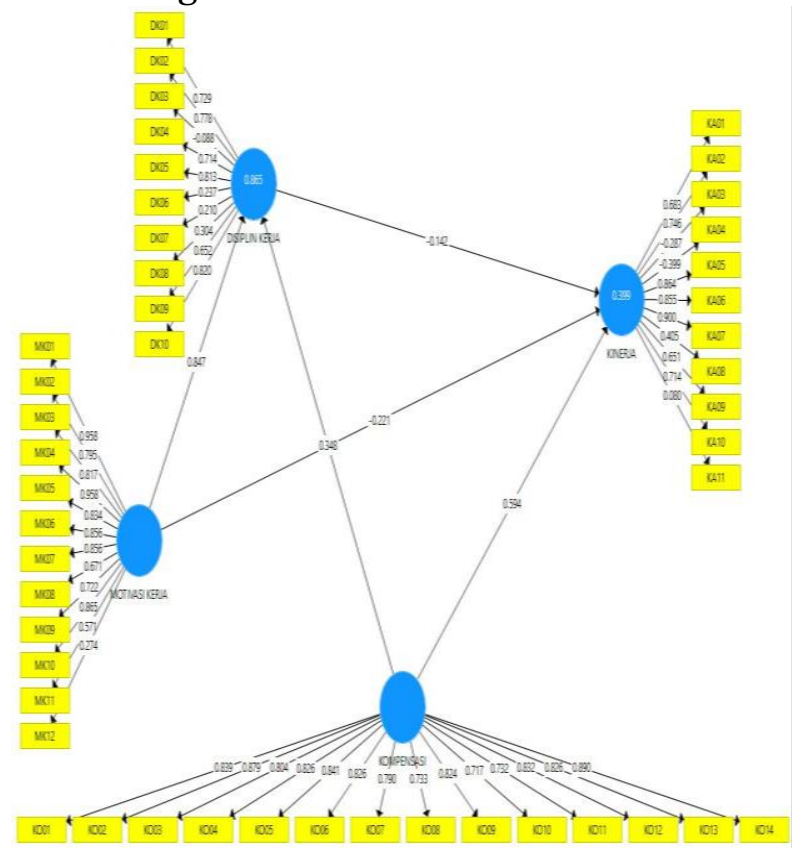

Gambar 4.

Output Koefisien Jalur 


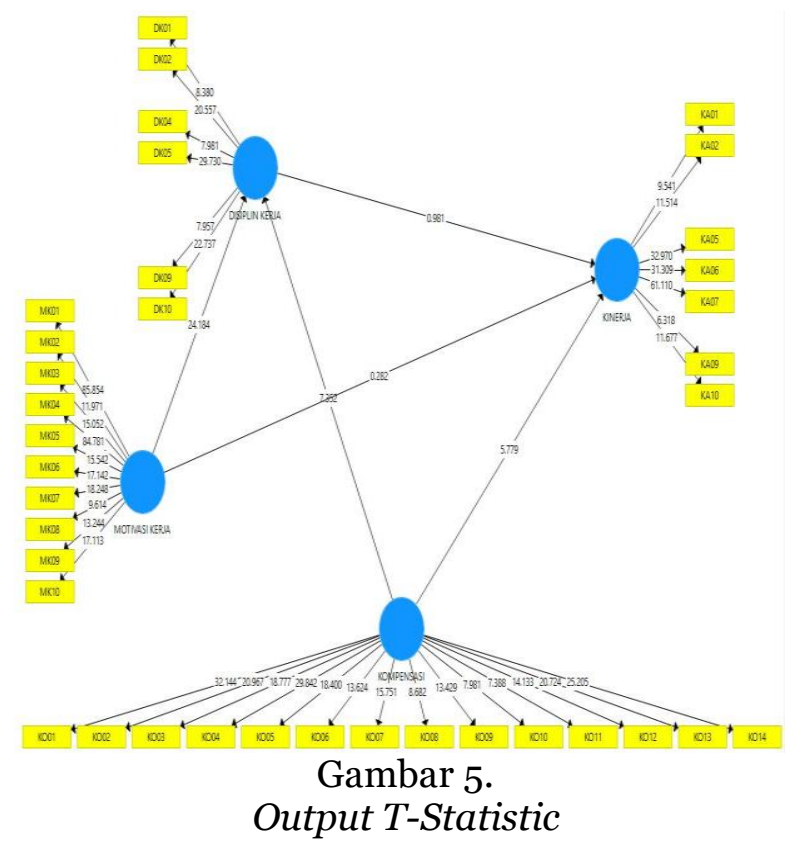

Dari hasil uji hipotesis diatas, dapat diketahui bahwa dua hipotesis berpengaruh tidak signifikan dan tiga hipotesis berpengaruh signifikan.

\begin{tabular}{|c|c|c|c|c|c|}
\hline $\begin{array}{c}\text { Hipot } \\
\text { esis }\end{array}$ & $\begin{array}{c}\text { Pengaruh } \\
\text { antar } \\
\text { Variabel }\end{array}$ & $\begin{array}{c}\text { Path } \\
\text { Koefisien }\end{array}$ & $\begin{array}{c}\text { Besar } \\
\text { Pengaru } \\
\mathbf{h}\end{array}$ & $\begin{array}{c}T \\
\text { Statistics }\end{array}$ & T Tabel \\
\hline H1 & $\begin{array}{l}\text { Disiplin Kerja } \\
\rightarrow>\text { Kinerja } \\
\text { Pegawai }\end{array}$ & $-0,291$ & $-29,1 \%$ & 0,981 & 1,96 \\
\hline $\mathrm{H} 2$ & $\begin{array}{l}\text { Motivasi } \\
\text { Kerja -> } \\
\text { Kinerja } \\
\text { Pegawai }\end{array}$ & $-0,062$ & $-0,62 \%$ & 0,282 & 1,96 \\
\hline $\mathrm{H}_{3}$ & $\begin{array}{l}\text { Kompensasi - } \\
\text { > Disiplin } \\
\text { Kerja }\end{array}$ & 0,398 & $39,8 \%$ & 7,352 & 1,96 \\
\hline $\mathrm{H}_{4}$ & $\begin{array}{l}\text { Motivasi } \\
\text { Kerja-> } \\
\text { Disiplin Kerja }\end{array}$ & 0,847 & $84,7 \%$ & 24,184 & 1,96 \\
\hline $\mathrm{H}_{5}$ & $\begin{array}{l}\text { Kompensasi - } \\
>\text { Kinerja } \\
\text { Pegawai }\end{array}$ & o,619 & $61,9 \%$ & 5,779 & 1,96 \\
\hline
\end{tabular}

\section{Pengaruh Disiplin Kerja (X1) Terhadap Kinerja Pegawai (Y)}

Pengujian hipotesis pertama dilakukan untuk menguji pengaruh variabel Disiplin Kerja (X1) terhadap variabel Kinerja Pegawai
(Y). Pembuktian ada tidaknya pengaruh yang signifikan dilakukan dengan membandingkan nilai t-statistik hasil dari bootstrapping dengan t-tabel. Berdasarkan tabel 4.7, diketahui nilai t hitung lebih kecil dari t tabel, yaitu: 0,981 lebih kecil dari 1,96. Hal ini dapat disimpulkan bahwa Disiplin Kerja (X1) terbukti berpengaruh tidak signifikan terhadap variabel Kinerja Pegawai (Y) pada taraf signifikansi $5 \%$, dengan besar pengaruh 29,1\%. Koefisien arah hubungan berbentuk negatif. Pola hubungan yang terbentuk bersifat negatif, artinya jika Disiplin Kerja tinggi, belum tentu akan meningkatkan Kinerja para pegawainya, dan sebaliknya jika Disiplin Kerja rendah maka akan meningkatkan Kinerja para pegawainya. Walaupun demikian, pola hubungan yang negatif ini tidak memberikan pengaruh yang kuat terhadap Kinerja Pegawai karena hanya berpengaruh sebesar 29,1\%.

Hasil penelitian ini sesuai dengan hasil penelitian yang telah dilakukan oleh Agung Setiawan yang menyatakan bahwa Disiplin Kerja berpengaruh negatif dan tidak signifikan terhadap Kinerja Pegawai pada Rumah Sakit Umum Daerah (RSUD) Kanjuruhan Malang. Namun penelitian tersebut berbeda dengan penelitian yang telah dilakukan oleh Betaria Simanjuntak dan Arif yusuf Hamali yang menyatakan bahwa Disiplin Kerja berpengaruh signifikan terhadap Kinerja Pegawai pada PT Bank BNI 46, kantor cabang Asia Afrika Bandung.

\section{Pengaruh Motivasi Kerja (X2) Terhadap Kinerja Pegawai (Y)}

Pengujian hipotesis kedua dilakukan untuk menguji pengaruh variabel Motivasi Kerja (X2) terhadap variabel Kinerja Pegawai (Y). Pembuktian ada tidaknya pengaruh yang signifikan dilakukan dengan membandingkan nilai t-statistik hasil dari bootstrapping dengan t-tabel. Berdasarkan tabel 4,7, diketahui nilai t hitung lebih kecil dari t tabel, yaitu: 0,282 lebih kecil dari 1,96. Hal ini dapat disimpulkan bahwa Motivasi Kerja (X2) terbukti berpengaruh tidak signifikan terhadap variabel Kinerja Pegawai (Y) pada taraf signifikansi 5\%, dengan besar pengaruh - 
0,29\%. Koefisien arah hubungan berbentuk negatif. Pola hubungan yang terbentuk bersifat negatif, artinya jika Motivasi Kerja tinggi, belum tentu akan meningkatkan Kinerja para pegawainya, dan sebaliknya jika Motivasi Kerja rendah maka akan meningkatkan Kinerja para pegawainya. Walaupun demikian, pola hubungan yang negatif ini tidak memberikan pengaruh yang kuat terhadap Kinerja Pegawai karena hanya berpengaruh sebesar $0,29 \%$.

Hasil penelitian ini sesuai dengan hasil penelitian yang telah dilakukan oleh Yuli Suwati yang menyatakan bahwa Motivasi Kerja berpengaruh negatif dan tidak signifikan terhadap Kinerja Pegawai pada PT Tunas Hijau Samarinda. Namun penelitian tersebut berbeda dengan penelitian yang telah dilakukan oleh M Harlie yang menyatakan bahwa Motivasi Kerja berpengaruh signifikan terhadap Kinerja Pegawai Negeri Sipil pada Pemerintahan Kabupaten Tabalong di Tanjung Kalimantan Selatan. Dan hasil penelitian yang telah dilakukan oleh Aries Susanty, Sigit Wahyu Baskoro yang menyatakan bahwa Motivasi Kerja berpengaruh signifikan terhadap kinerja dari karyawan PT. PLN (Persero) APD Semarang.

\section{Pengaruh Kompensasi (X3) Terhadap Disiplin Kerja (X1)}

Pengujian hipotesis ketiga dilakukan untuk menguji pengaruh variabel Kompensasi (X3) terhadap variabel Disiplin Kerja (X1). Pembuktian ada tidaknya pengaruh yang signifikan dilakukan dengan membandingkan nilai t-statistik hasil dari bootstrapping dengan t-tabel. Berdasarkan tabel 4.7, diketahui nilai t hitung lebih besar dari t tabel, yaitu: 7,352 lebih besar dari 1,96. Hal ini dapat disimpulkan bahwa Kompensasi (X3) terbukti berpengaruh signifikan terhadap variabel Disiplin Kerja (X1) pada taraf signifikansi 5\%, dengan besar pengaruh 38,3\%. Pola hubungan yang terbentuk juga positif artinya semakin baik Kompensasi maka semakin baik pula Disiplin Kerja pegawai di bagian Record Management dan Partnership Operation dengan besar pengaruh sebesar 38,3\%.
Hasil penelitian ini sesuai dengan hasil penelitian yang telah dilakukan oleh Puput Maretha Sari, Supardi A. Bakri, \& Yuliansyah M Diah yang menyatakan bahwa Kompensasi berpengaruh positif dan signifikan terhadap Disiplin Kerja Pegawai Pada Lembaga Penjaminan Mutu Pendidikan Sumatera Selatan. Kemudian penelitian ini juga sesuai dengan hasil penelitian yang telah dilakukan oleh Asmawar, Mukhlis Yunus, Amri yang menyatakan bahwa Kompensasi berpengaruh positif dan signifikan terhadap Disiplin Kerja Pegawai Negeri Sipil Dinas Kesehatan Kabupaten Aceh Jaya.

\section{Pengaruh Motivasi Kerja (X2) Terhadap Disiplin Kerja (X1)}

Pengujian hipotesis keempat dilakukan untuk menguji pengaruh variabel Motivasi Kerja (X2) terhadap variabel Disiplin Kerja (X1). Pembuktian ada tidaknya pengaruh yang signifikan dilakukan dengan membandingkan nilai t-statistik hasil dari bootstrapping dengan t-tabel. Berdasarkan tabel 4.7, diketahui nilai t hitung lebih besar dari t tabel, yaitu: 24,184 lebih besar dari 1,96. Hal ini dapat disimpulkan bahwa Motivasi Kerja (X2) terbukti berpengaruh signifikan terhadap variabel Disiplin Kerja (X1) pada taraf signifikansi $5 \%$, dengan besar pengaruh $84,7 \%$. Pola hubungan yang terbentuk juga positif artinya semakin baik Motivasi Kerja maka semakin baik Disiplin Kerja pegawai di bagian Record Management dan Partnership Operation dengan besar pengaruh sebesar $84,7 \%$. Untuk mengetahui indikator mana yang paling mempengaruhi Disiplin Kerja dan Motivasi Kerja.

Hasil penelitian ini sesuai dengan hasil penelitian yang telah dilakukan oleh Dyah Nur Dwiyanti yang menyatakan bahwa Motivasi Kerja berpengaruh positif dan signifikan terhadap Disiplin Kerja Pegawai Pada Dinas Pemuda Dan Olahraga Provinsi Riau. Kemudian penelitian ini juga sesuai dengan penelitian yang telah dilakukan oleh M Bisri Wahid, Karnadi yang menyatakan bahwa Motivasi Kerja berpengaruh signifikan 
terhadap Disiplin Kerja Pelaksana Pemerintahan Desa Wringinagung Gambiran Banyuwangi.

\section{Pengaruh Kompensasi (X3) Terhadap Kinerja Pegawai (Y)}

Pengujian hipotesis kelima dilakukan untuk menguji pengaruh variabel Kompensasi (X3) terhadap variabel Kinerja Pegawai (Y). Pembuktian ada tidaknya pengaruh yang signifikan dilakukan dengan membandingkan nilai t-statistik hasil dari bootstrapping dengan t-tabel. Berdasarkan tabel 4.5, diketahui nilai thitung lebih besar dari t tabel, yaitu: 5,502 lebih besar dari 1,96. Hal ini dapat disimpulkan bahwa Kompensasi (X3) terbukti berpengaruh signifikan terhadap variabel Kinerja Pegawai (Y) pada taraf signifikansi $5 \%$, dengan besar pengaruh 60,3\%. Pola hubungan yang terbentuk juga positif artinya semakin baik Kompensasi maka semakin baik Kinerja Pegawai di bagian Record Management dan Partnership Operation dengan besar pengaruh sebesar 60,3\%. Untuk mengetahui indikator mana yang paling mempengaruhi Kompensasi dan Kinerja Pegawai.

Hasil penelitian ini relevan dengan penelitian yang dilakukan oleh Ririvega Kasenda yang menghasilkan penelitian Kompensasi berpengaruh signifikan terhadap Kinerja Pegawai di PT. Bangun Wenang Beverages Company Manado. Kemudian penelitian yang dilakukan oleh Ayesha Aslam, Amna Ghaffar, Tahleel Talha, dan Hina Musthaq yang menghasilkan penelitian Kompensasi berpengaruh signifikan terhadap Kinerja Pegawai di Bank Pakistan. Namun penelitian ini berbeda dengan penelitian yang dilakukan oleh Windy Aprilia Murty Gunasti Hudiwinarsih yang menyatakan bahwa Kompensasi berpengaruh tidak signifikan terhadap Kinerja Pegawai di bagian Akuntansi (Studi Kasus Pada Perusahaan Manufaktur di Surabaya).

\section{KESIMPULAN}

1. Tidak terdapat pengaruh yang signifikan dari Disiplin Kerja terhadap Kinerja
Pegawai pada Bank OCBC NISP Bagian RCMPO. Hal ini berdasarkan hasil olah data dengan PLS-SEM yang menunjukkan nilai $T$ Statistics adalah 0.981 lebih kecil dari 1.96. Evaluasi terkait kedisiplinan yang dilakukan oleh managemen belum sepenuhnya dilakukan ke dalam semua hal atau semua lini yang terkait dengan tata tertib di lingkungan kerja. Hal ini yang dirasakan oleh sebagian responden yang ada di Bagian RCMPO, dan menjadikan penyebab tidak terdapat pengaruh yang signifikan dari Disiplin Kerja terhadap Kinerja Pegawai jika dilihat dari distribusi jawaban responden atas pernyataan dalam kuesioner penelitian;

2. Tidak terdapat pengaruh yang signifikan dari Motivasi Kerja terhadap Kinerja Pegawai pada Bank OCBC NISP Bagian Bagian RCMPO. Hal ini berdasarkan hasil olah data dengan PLS-SEM yang menunjukkan nilai $T$ Statistics adalah 0,282 lebih kecil dari 1.96. Pimpinan organisasi saat ini belum sepenuhnya memberi dukungan atas perkembangan diri pegawainya, baik itu dalam segi karir ataupun pengembangan bakat yang dimiliki oleh masing-masing pegawinya, sehingga beberapa responden merasa tidak yakin dengan pernyataan tersebut jika dilihat dari distribusi jawaban responden atas pernyataan dalam kuesioner penelitian;

3. Terdapat pengaruh yang signifikan dari Kompensasi terhadap Disiplin Kerja Pegawai pada Bank OCBC NISP Bagian RCMPO. Hal ini berdasarkan hasil olah data dengan PLS-SEM yang menunjukkan nilai $T$ Statistics adalah 7,352 lebih besar dari 1.96. Hal ini sudah teruji, jika semakin tinggi tingkat kompensasi, maka akan semakin tinggi pula tingkat disiplin kerja pegawai. Pegawai memahami sanksi apa saja yang akan diberikan oleh manajemen jika tidak menjalankan tata tertib yang berlaku, artinya pegawai bisa menjalankan semua aturan atau tata tertib yang diterapkan pada lingkungan kerja, sejalan dengan itu manajemen akan mengapresiasi dalam bentuk kompensasi. Hal ini menjadi penyebab terdapat pengaruh yang signifikan dari Kompensasi terhadap 
Disiplin Kerja pegawai pada Bank OCBC NISP Bagian Record Management dan Partnership Operation jika dilihat dari distribusi jawaban responden atas pernyataan dalam kuesioner penelitian;

4. Terdapat pengaruh yang signifikan dari Motivasi Kerja terhadap Disiplin Kerja Pegawai pada Bank OCBC NISP Bagian RCMPO. Hal ini berdasarkan hasil olah data dengan PLS-SEM yang menunjukkan nilai $T$ Statistics adalah 24,184 lebih dari 1.96. Hal ini sudah teruji, jika semakin tinggi tingkat motivasi kerja, maka akan semakin tinggi pula tingkat disiplin kerja pegawai. Pegawai memahami sanksi apa saja yang akan diberikan oleh manajemen jika tidak menjalankan tata tertib yang berlaku atau tidak disiplin, dengan kata lain disini pegawai bisa menjalankan semua aturan atau tata tertib yang diterapkan pada lingkungan kerja dan tingkat attention pimpinan yang tinggi terhadap pekerjaan bawahannya menjadi penyebab terdapat pengaruh yang signifikan dari Motivasi Kerja terhadap Disiplin Kerja pegawai pada Bank OCBC NISP Bagian Record Management dan Partnership Operation jika dilihat dari distribusi jawaban responden atas pernyataan dalam kuesioner penelitian.

5. Terdapat pengaruh yang signifikan dari Kompensasi terhadap Kinerja Pegawai pada Bank OCBC NISP Bagian RCMPO. Hal ini berdasarkan hasil olah data dengan PLSSEM yang menunjukkan nilai $T$ Statistics adalah 5.779 lebih besar dari 1.96. Dalam hal ini sudah teruji, jika semakin maksimal kompensasi yang diberikan oleh perusahaan, maka akan semakin meningkatkan kinerja pegainya itu sendiri. Kompensasi juga mengandung adanya hubungan yang sifatnya profesional dimana salah satu tujuan utama pegawai bekerja adalah mendapatkan imbalan untuk mencukupi berbagai kebutuhan, sementara disisi perusahaan mereka membayar pegawai agar para pegawai bisa menjalankan pekerjaan sesuai dengan keinginan dan harapan perusahaan dengan tujuan utama mampu memajukan jalannya usaha perusahaan. Dari uraian tersebut diatas, hal tersebut dapat dikatakan menjadi penyebab terdapat pengaruh yang signifikan dari Kompensasi terhadap Kinerja pegawai pada Bank OCBC NISP Bagian Record Management dan Partnership Operation.

\section{SARAN}

1. Manajemen Bank OCBC NISP diharapkan melakukan evaluasi secara periodik terkait kedisiplinan dan diaplikasikan ke dalam semua hal atau semua lini yang terkait dengan tata tertib di lingkungan kerja. Perlu konsistensi baik dari manajemen maupun dari pimpinan organisasi agar evaluasi kedisiplinan ini terus berjalan. Dari evaluasi ini diharapkan pegawai akan semakin paham dan aware terhadap tata tertib (tatib) yang berlaku.

2. Pimpinan organisasi diharapkan lebih memperhatikan akan perkembangan diri dari pegawainya, baik itu dalam karir ataupun pengembangan bakat yang dimiliki oleh masing-masing pegawinya. Pada tingkatan ini, individu memiliki kebutuhan untuk berprestasi dan mendapat pengakuan serta penghargaan dari orang lain.

3. Manajemen Bank OCBC NISP diharapkan lebih memperhatikan kebijakan terkait Disiplin Kerja di lingkungan kerja yang sudah ada karena kebijakan yang berlaku saat ini belum mendukung pegawai untuk memiliki tingkat disiplin kerja yang lebih baik. Dan pimpinan organisasi bisa lebih memperhatikan attention terhadap bawahannya. Karena dari pengujian ini didapati, jika tingkat motivasi kerja pegawai tinggi maka akan sangat mempengaruhi tingkat disiplin kerja pegawai nya.

4. Manajemen Bank OCBC NISP khususnya pimpinan organisasi di Bagian RCMPO diharapkan lebih memperhatikan faktor utama yang berpengaruh terhadap kinerja pegawai yaitu Kompensasi, hal ini guna meningkatkan kinerja pegawai secara optimal. Karena kompensasi merupakan apa yang seorang pekerja terima sebagai balasan dari pekerjaan yang diberikannya. Dan dapat dijelaskan bahwa, jika 
manajemen memberikan kompensasi yang sesuai, maka pegawai akan memberikan kontribusi mereka secara maksimal. Karena dari pengujian ini didapati, jika tingkat kompensasi semakin maksimal maka akan sangat mempengaruhi tingkat disiplin kerja dan kinerja pegawai nya.

\section{DAFTAR PUSTAKA}

Asim, Masood. (2013). International Journal of Scientific and Research Publications. Impact of Motivation on Employee Performance with Effect of Training: Specific to Education Sector of Pakistan. 3 (9), 1-9.

Aslam, Ayesha., Ghaffar, Amma., Talha, Tahleel., \& Musthaq, Hina. (2015). European Journal of Business and Social Sciences. Impact of Compensation and Reward system on the performace of an organization, an empirical study on banking sector of Pakistan. 4 (8), 319-325.

Asmawar., Yunus, Mukhlis Yunus., \& Amri. (2014). Jurnal Manajemen. Pengaruh Kompensasi Dan Pengawasan Pimpinan Terhadap Disiplin Dan Dampaknya Pada Peningkatan Kinerja Pegawai Negeri Sipil Dinas Kesehatan Kabupaten Aceh Jaya. 3 (1). 10-16.

Brahmasari, Ida Ayu., \& Suprayetno, Agus. (2008). Jurnal Manajemen dan Kewirausahaan. Pengaruh Motivasi Kerja, Kepemimpinan dan Budaya Organisasi Terhadap Kepuasan Kerja Karyawan serta Dampaknya pada Kinerja Perusahaan (Studi kasus pada PT. Pei Hai International Wiratama Indonesia), 10 (2), 124-135.

Colquitt, Jason A., LePine, Jeffery A., \& Wesson, Michael J. (2015). Organizational Behavior. New York, McGraw-Hill Education.

Edison, Emron., Anwar, Yohny., \& Komariyah, Imas. (2017). Manajemen Sumber Daya Manusia. Bandung, Alfabeta.

Grifin, Ricky W., \& Moorhead, Gregory. (2013). Organizational Behavior. South-Western, Cengage Learning.
Hasibuan, Malayu S.P. (2017). Manajemen Sumber Daya Manusia. Remaja Rosdakarya.

Hellriegel, Don., \& Slocum, John W. (2011). Organizational Behavior. SouthWestern, Cengage Learning.

Kasenda, Ririvega. (2013). Jurnal EMBA. Kompensasi Dan Motivasi Pengaruhnya Terhadap Kinerja Karyawan Pada PT. Bangun Wenang Beverages Company Manado. 1 (3). 853-859.

Khoir, Dhany Hamiddan. (2012). FaktorFaktor ang mempengaruhi Kinerja Pegawai pada Direktorat Pembinaan Sekolah Dasar Ditjen Pendidikan Dasar Kemdikbud. 1-113.

Luthans, Fred. (2011). Organizational Behavior. New York, McGrawHill/Irwin.

Mangkunegara, Anwar Prabu. (2015). Manajemen Sumber Daya Manusia Perusahaan. Bandung, Remaja Rosdakarya.

Mcshane, Steven L., \& Glinow, Mary Ann Von. (2008). Organizational Behavior. New

York, McGraw-Hill/Irwin.

Murty, Windy Aprilia., \& Hudiwinarsih, Gunasti. (2012). Jurnal The Indonesian Accounting Review. Pengaruh Kompensasi, Motivasi Dan Komitmen Organisasional Terhadap Kinerja Karyawan Bagian Akuntansi (Studi Kasus Pada Perusahaan Manufaktur Di Surabaya). 2 (2). 215-228.

Robbins, Stephen P., \& Judge, Timothy A. (2013). Organizational Behavior. New Jersey, Pearson Education.

Sari, Puput Maretha., Bakri, Supardi A., \& Yuliansyah. (2015). Jurnal Ilmiah Manajemen Bisnis Dan Terapan. Pengaruh Kompensasi Terhadap Disiplin Kerja Pegawai Pada Lembaga Penjaminan Mutu Pendidikan Sumatera Selatan. XII (2). 87-95.

Schermerhorn, John R., Hunt, James G., Osborn, Richard N., \& Uhl-Bien, Mary. (2010). Organizational Behavior. Hoboken, John Wiley \& Sons, Inc.

Setiawan, Agung. (2013). Jurnal Ilmu Manajemen. Pengaruh Disiplin Kerja 
Dan Motivasi Terhadap Kinerja Karyawan Pada Rumah Sakit Umum Daerah Kanjuruhan Malang. 1 (4), 1245-1253.

Siagian, Sondang P. (2016). Manajemen Sumber Daya Manusia. Jakarta, Bumi Aksara.

Simanjuntak, Betaria., \& Hamali, Arif Yusuf. (2016). Junral Banking and Management Review. Pengaruh Disiplin Kerja Terhadap Kinerja Pegawai Pada PT. Bank BNI 1946 (Persero) Tbk. Kantor Cabang Asia Afrika Bandung. 5 (1). 575-585.

Sinambela, Lijan Poltak. (2012). Kinerja Pegawai. Yogyakarta, Graha Ilmu.

Sinambela, Lijan Poltak. (2017). Manajemen Sumber Daya Manusia. Jakarta, Bumi Aksara.

Soehardi dan Sherlito C. Sable, (2019). Strategi Pemasaran Bisnis Pariwisata di Kota Davao, Filipina. Jakarta: Jurnal Ilmiah Manajemen Ubhara atau http://jurnal.ubharajaya.ac.id/index.p hp/manajemen-ubhara

Sugiyono. (2014). Metode Penelitian Bisnis. Bandung, Alfabeta.

Sukmawati, Ferina. (2208). Jurnal Ekonomi dan Bisnis. Pengaruh Kepemimpinan, Lingkungan Kerja Fisik, dan Kompensasi terhadap Kinerja Karyawan di PT PERTAMINA (Persero) UPMS III Terminal Trnasit Utama Balongan, Indramayu. 2 (3), 175-194.

Suparyadi. (2015). Manajemen Sumber Daya Manusia. Yogyakarta, Andi Offset.

Susanty, Aries., \& Baskoro, Sigit Wahyu. (2012). Jurnal Teknik Industri. Pengaruh Motivasi Kerja dan Gaya Kepemimpinan terhadap Disiplin Kerja serta dampaknya pada Kinerja Karyawan. (Studi Kasus Pada PT. PLN (PERSERO) APD Semarang). 7 (2). 77-84.

Sutrisno, Edy. (2016). Manajemen Sumber Daya Manusia. Jakarta, Prenadamedia Group.

Suwati, Yuli. (2013). Jurnal Ilmu Administrasi Bisnis. Pengaruh Kompensasi dan Motivasi Kerja terhadap Kinerja karyawan pada PT Tunas Hijau Samarinda. 1 (1), 41-55.

Wahjono, Sentot Imam. (2010). Perilaku Organisasi. Yogyakarta, Graha Ilmu.

Wibowo. (2016). Manajemen Kinerja. Depok, Rajagrafindo Persada. 